International Journal of Mechanical Engineering and Technology (IJMET)

Volume 11, Issue 10, October 2020, pp. 19-27, Article ID: IJMET_11_10_003

Available online at https://iaeme.com/Home/issue/IJMET?Volume $=11 \&$ Issue $=10$

ISSN Print: 0976-6340 and ISSN Online: 0976-6359

DOI: https://doi.org/10.34218/IJMET.11.10.2020.003

\title{
EXPERIMENTAL INVESTIGATIONS ON INJECTION TIMING VARIATION AT AN INJECTOR OPENING PRESSURE OF 190BAR ON SEMI- ADIABATIC DIESEL ENGINE WITH EXHAUST GAS RECIRCULATION
}

\author{
G. Sayanna \\ Department of Mechanical Engineering, University College of Engineering (A), \\ Osmania University-Hyderabad, Telangana. India

\section{M.V.S. Murali Krishna} \\ Mechanical Engineering Department, Chaitanya Bharathi Institute of Technology, \\ Gandipet, Hyderabad, Telangana, India.

\section{P. Usha Sri} \\ Department of Mechanical Engineering, University College of Engineering (A), \\ Osmania University, Telangana. India
}

\begin{abstract}
Particulate emissions and Nitrogen oxides (NOx) levels are exhaust emissions from compression ignition (CI) engine. Once they are in-haled-in, they cause health hazards, besides environmental impact. Hence control of these emissions are important and an urgent task. In the context of depletion of fossil fuels, coupled with exponential growth rate of traction power engines in automobiles and for human luxuries, energy consumption has increased by many folds. This has triggered ever increase of fuel prices in international market and due to uneven distribution of oil resources in the world, a few oil rich countries are getting benefitted and oil lacking countries are suffering from non- affordability. Alcohols and vegetable oils are important substitutes for diesel fuel, as they are renewable. However, drawbacks associated with vegetable oils (high viscosity and low volatility) and alcohols (low cetane number and calorific value of the alcohols) call for low heat rejection (LHR) diesel engine. Exhaust gas recirculation (EGR) is one of the techniques to reduce pollution levels. Investigations were carried out to determine exhaust emissions of particulate matter and oxides of nitrogen with neat diesel operation at different values of brake mean effective pressure of the engine with varied injection timing with provision of
\end{abstract}


Experimental Investigations on Injection Timing Variation at an Injector Opening Pressure of 190bar on Semi- Adiabatic Diesel Engine with Exhaust Gas Recirculation

EGR and compared the data with conventional engine with neat diesel operation. LHR engine consisted of air gap insulated piston with Stainless Steel crown, a low thermal conductivity material and air gap insulated liner with Stainless Steel insert. Particulate matter and NOx emissions will reduce with optimum EGR system.

Keywords: Particulate Emissions(PM), Nitrogen Oxides (NOx), LHR engine, Injection Timing and Exhaust Gas Recirculation (EGR).

Cite this Article: G. Sayanna, M.V.S. Murali Krishna and P. Usha Sri, Experimental Investigations on Injection Timing Variation at an Injector Opening Pressure of 190bar on Semi- Adiabatic Diesel Engine with Exhaust Gas Recirculation. International Journal of Mechanical Engineering and Technology. 11(10), 2020, pp. 19-27.

https://iaeme.com/Home/issue/IJMET?Volume $=11 \&$ Issue $=10$

\section{INTRODUCTION}

Energy demand (Lee, et al, 2014) is increasing due to ever increasing number of vehicles employing internal combustion engines (Haywood , 2013). World is presently confronted with the twin crisis of fossil fuel depletion and environmental degradation. Fossil fuels are limited resources; hence, search for renewable fuels is becoming more and more prominent for ensuring energy security (Murali Krishna et al, 2014) and environmental protection. In the context of fast depletion of fossil fuels, ever increase of fuel prices and increase of pollution levels with fossil fuels, the search for alternative techniques has become pertinent. The concept of the engine with LHR combustion chamber (Murali Krishna et al, 2014a) is to reduce heat loss to the coolant, by providing thermal resistance in the path of heat flow to the coolant. Any saving in this part of the energy distribution would either increase the energy lost through exhaust gases or increase the power output. Considerable efforts are under way to reduce heat loss to the coolant by various researchers (Murali Krishna et al, 2015; Dinagar, et al, 1993). However, the results are a little confusing as to whether the insulation would improve or deteriorate thermal efficiency. The approach being pursued to decrease heat rejection Ceramic Coating LHR combustion chamber with low thermal conductivity materials on crown of the piston, inner portion of the liner and cylinder head with Superni-90. The major pollutants emitted from diesel engine are particulate emissions and $\mathrm{NO} x$

Automobile exhausts reach ocean in the form of acid rain, there by polluting water. Hence control of these emissions is an immediate task and important. Hence globally, stringent regulations are made for permissible pollutants in the exhaust of the engines. In diesel engines, it is rather difficult to lower $\mathrm{NO}_{\mathrm{X}}$ and $\mathrm{PM}$ emissions simultaneously due to soot-NOX trade off. High $\mathrm{NO}_{\mathrm{x}}$ and PM emissions are still the main obstacle in the development of next generation conventional diesel engines. There are many methods like employing improved exhaust gas after-treatment technologies, higher fuel injection pressures (Cole et al, 1985), split and multiple injections (Celikten, 2003), exhaust gas recirculation (EGR), intake air pressure boosting etc. are being applied to reduce particulate matter emissions and $\mathrm{NO}_{\mathrm{x}}$ levels in the exhaust of the compression ignition engine. LHR engine reduces particulate emission due to improved combustion. However, the major problem with any type of LHR engine is it increases drastically $\mathrm{NO}_{\mathrm{x}}$ levels in comparison with $\mathrm{CE}$ with neat diesel operation. There are many methods to reduce NOx levels like varying engine parameters, Selective Catalytic Reduction Technique (Janardhan. et al, 2012) SCRT and EGR. The method of SCRT is tedious where zeolites are used. EGR offers simple solution where exhaust gas is re circulated (Vamshi Krishnan et al, 2018) to inlet manifold of the engine levels. Inhaling of these 
pollutants causes health hazards like severe headache, tuberculosis, lung cancer, dizziness, nausea, respiratory problems, skin cancer and Head hemorrhage.

\section{MATERIALS AND METHODS}

\subsection{Fabrication of engine with LHR combustion chamber}

Fig.1 shows assembly details of air gap insulated piston, air gap insulated liner and LHR combustion chamber. The top portion of the piston, crown made of low thermal conductivity material, stainless steel was screwed to aluminum body of the piston, providing optimum thickness of $2.8 \mathrm{~mm}$ air gap in between the crown and the body of the piston. A Stainless Steel (SS) insert was screwed to the top portion of the liner in such a manner that optimum thickness of an air gap of $2.8 \mathrm{~mm}$ was maintained between the insert and the liner body. The combination of low thermal conductivity materials of air and SS provide sufficient insulation for heat flow to the coolant thus resulted in LHR combustion chamber.
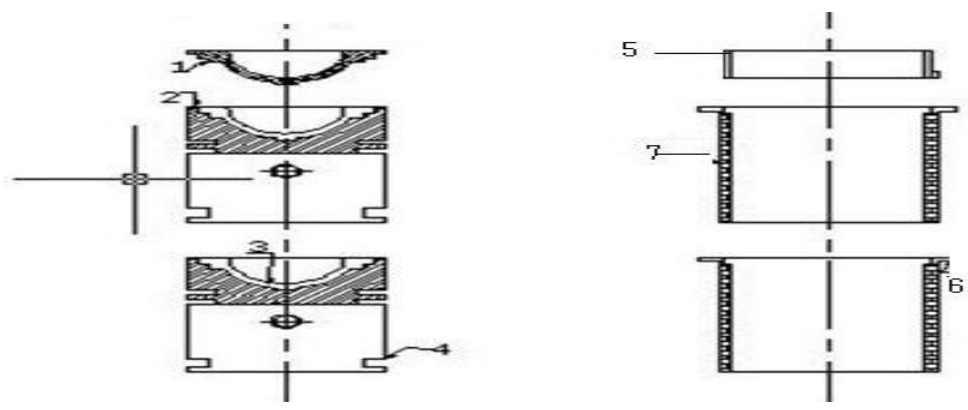

1. Stainless Steel with threads, 2.SS gasket, 3. Air gap in piston, 4. Body of piston, 5.SS insert with threads, 6. Air gap in liner, 7.Liner

Figure 1 Assembly details of air gap insulated piston and air gap insulated liner

The photographic views of air gap insulated piston and air gap insulated liner are shown in Fig.2.
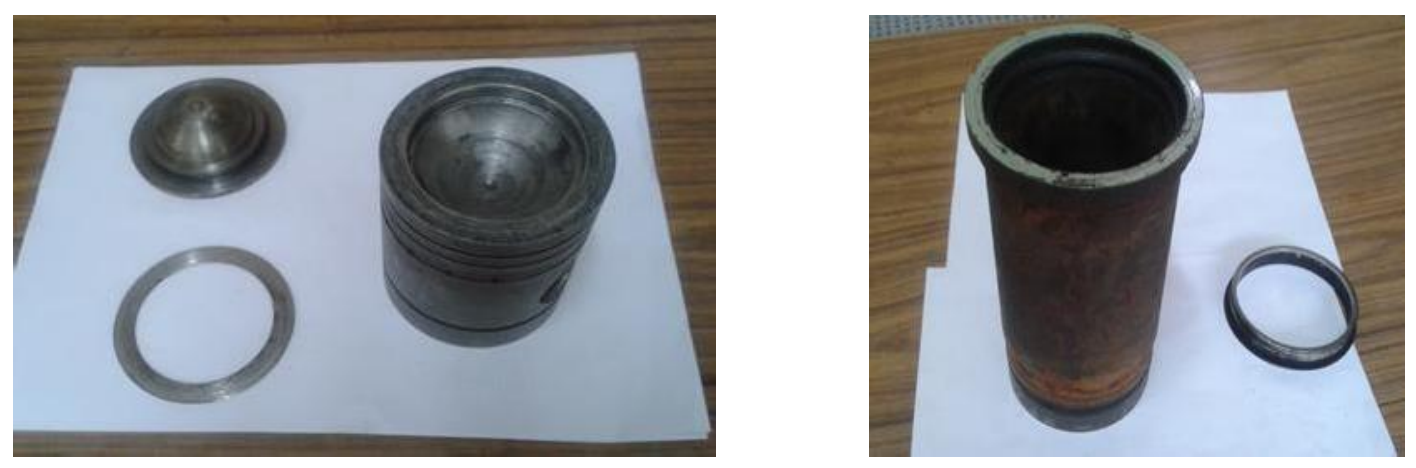

Figure 2 The photographs of air gap insulated piston and air gap insulated liner

\subsection{Experimental set-up}

The Fig. 3 shows schematic diagram of the experimental setup used for the investigations on the engine with LHR combustion chamber with diesel. Accuracy of the instruments is shown in Table.1. Specifications of the test engine are given in Table 2. The engine tests are carried out with a single-cylinder, four-stroke, naturally aspirated, water cooled, direct-injection compression ignition engine of brake power $3.68 \mathrm{~kW}$ operated at a constant speed of 1500 $\mathrm{rev} / \mathrm{min}$. The compression ratio of the engine is $16: 1$. The engine is connected to an electric dynamometer for measuring its brake power. Dynamometer is loaded by a loading rheostat. 
Experimental Investigations on Injection Timing Variation at an Injector Opening Pressure of 190bar on Semi- Adiabatic Diesel Engine with Exhaust Gas Recirculation

The fuel consumption is registered with an aid of fuel measuring device (Burette and stop watch). Diesel is injected into the engine through conventional injection system. Air consumption of the engine was obtained with an aid of air-box, orifice flow meter and U-tube water manometer assembly.

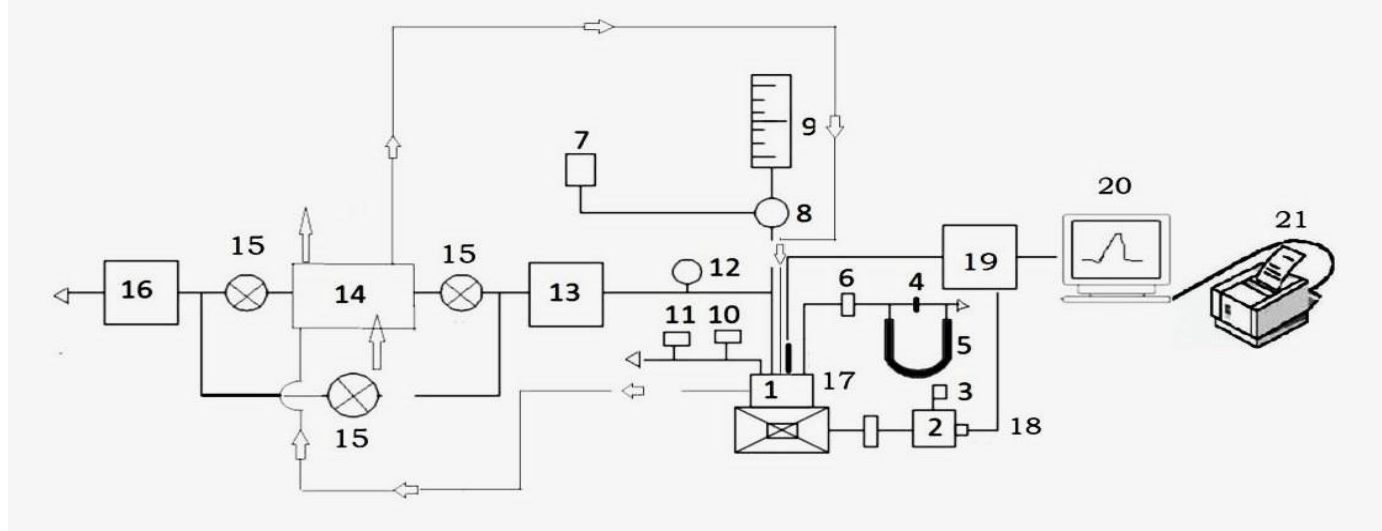

1.Engine, 2.Electical Dynamometer, 3.Load Box, 4.Orifice meter, 5.U-tube water manometer, 6.Air-box, 7.Fuel tank, 9.Burette, 10.Outlet jacket water temperature indicator,11. Outlet jacket water flow meter,12. Exhaust gas temperature indicator, 13. AVL Smoke meter. 14. Heat exchanger (HE), 15.Control valve.16. Netel Chromatograph $\mathrm{NO}_{\mathrm{X}}$ analyzer 17.Piezoelectric pressure transducer, 18. TDC encoder, 19.Console, 20.Personal computer 21.Printer.

Figure 3 Schematic diagram of experimental set-up

Air box with diaphragm is used to damp out the pulsations produced by the engine, for ensuring a steady flow of air through the intake manifold. Sensor method is provided to vary injection timing. Coolant water jacket inlet temperature, outlet jacket temperature and exhaust gas temperature are measured by employing iron and iron- constantan thermocouples connected to analogue temperature indicators.

Table 1 Accuracy of the Instruments

\begin{tabular}{|l|l|l|}
\hline \multicolumn{1}{|c|}{ Instrument } & \multicolumn{1}{c|}{ Purpose } & Accuracy \\
\hline EGT indicator & For measuring EGT & $5^{\circ} \mathrm{C}$ \\
\hline Tachometer & For measuring speed of the engine & $5 \mathrm{rpm}$ \\
\hline Burette & For measuring flow rate of fuel to the engine & $0.5 \mathrm{cc} / \mathrm{s}$ \\
\hline Stop watch & For noting down time taken for $10 \mathrm{cc}$ of fuel & $0.5 \mathrm{Sec}$ \\
\hline Hydrometer & For measuring density of fuel & $0.1 \mathrm{gm} / \mathrm{cc}$ \\
\hline Dynamometer & For measuring brake power of the engine & $1 \mathrm{watt}$ \\
\hline Water flow meter & For measuring water flow rate to the engine & $5 \mathrm{gm} / \mathrm{s}$ \\
\hline Particulate & For measuring particulate emissions & $1 \mathrm{HSU}$ \\
\hline Analyzer & & \\
\hline NOx Analyzer & For measuring nitrogen oxide levels & $5 \mathrm{ppm}$ \\
\hline
\end{tabular}

The naturally aspirated engine was provided with water-cooling system in which outlet temperature of water is maintained at $80^{\circ} \mathrm{C}$ by adjusting the water flow rate. The water flow rate is measured by means of analogue water flow meter. Engine oil is provided with a pressure feed system. No temperature control was incorporated, for measuring the lube oil temperature. EGR system is designed based upon mass flow rate of hot fluid, cold fluid and their temperatures so as to find out the length of heat exchanger. 
Table 2 Specifications of the test engine

\begin{tabular}{|l|l|}
\hline \multicolumn{1}{|c|}{ Description } & \multicolumn{1}{c|}{ Specification } \\
\hline Engine make and model & Kirloskar ( India) AV1 \\
\hline $\begin{array}{l}\text { Maximum power output at a speed } \\
\text { of } 1500 \mathrm{rpm}\end{array}$ & $3.68 \mathrm{~kW}$ \\
\hline $\begin{array}{l}\text { Number of cylinders } \times \text { cylinder } \\
\text { position } \times \text { stroke }\end{array}$ & One $\times$ Vertical position $\times$ four-stroke \\
\hline Bore $\times$ stroke & $80 \mathrm{~mm} \times 110 \mathrm{~mm}$ \\
\hline Method of cooling & Water cooled \\
\hline Rated speed $($ constant) & $1500 \mathrm{rpm}$ \\
\hline Fuel injection system & In-line and direct injection \\
\hline Compression ratio & $16: 1$ \\
\hline BMEP @ 1500 rpm & 5.31 bar \\
\hline Manufacturer's recommended & $27^{\circ}$ bTDC $\times 190$ bar \\
\hline injection timing and pressure & \\
\hline Dynamometer & Electrical dynamometer \\
\hline Number of holes of injector and size & Three $\times 0.25$ mm \\
\hline Type of combustion chamber & Direct injection type \\
\hline Fuel injection nozzle & Make: MICO-BOSCH \\
& No- 0431-202-120/HB \\
\hline Fuel injection pump & Make: BOSCH: NO- $8085587 / 1$ \\
\hline
\end{tabular}

EGR system is designed based upon mass flow rate of hot fluid, cold fluid and their temperatures so as to find out the length of heat exchanger.

\subsection{Exhaust Emissions}

The major pollutants emitted from diesel engine are particulate emissions and NOx levels. Inhaling of these pollutants causes health hazards like severe headache, tuberculosis, lung cancer, dizziness, nausea, respiratory problems, skin cancer, hemorrhage. The contaminated air containing carbon dioxide released from automobiles reaches ocean in the form of acid rain, there by polluting water. Hence control of these emissions is an immediate task and important. Hence globally, stringent regulations are made for permissible pollutants in the exhaust of the engines.

Exhaust emissions of particulate matter and nitrogen oxide $\left(\mathrm{NO}_{\mathrm{X}}\right)$ levels were recorded by AVL (A company trade name) Particulate matter analyzer and Netel Chromatograph (A company trade name) $\mathrm{NO}_{\mathrm{x}}$ analyzer at different values of brake mean effective pressure of the engine. The accuracy of Measurement of particulate emissions is \pm 1 HSU (Hartridge Smoke Unit), while it is $\pm 5 \mathrm{ppm}$ with $\mathrm{NO}_{\mathrm{X}}$ analyzer. The specifications and operating principle of the analyzers are given in Table 4.

Table 4 Specifications of gas analyzers

\begin{tabular}{|l|c|c|c|c|}
\hline \multicolumn{1}{|c|}{$\begin{array}{c}\text { Name of the } \\
\text { analyzer }\end{array}$} & $\begin{array}{c}\text { Measuring } \\
\text { Range }\end{array}$ & Precision & Resolution & $\begin{array}{c}\text { Accuracy of } \\
\text { Measurement }\end{array}$ \\
\hline $\begin{array}{l}\text { AVL } \\
\text { Particulate Matter } \\
\text { Analyzer }\end{array}$ & $0-100$ & $1 \mathrm{HSU}$ & $1 \mathrm{HSU}$ & $\pm 1 \mathrm{HSU}$ \\
\hline $\begin{array}{l}\text { Netel Chromatograph } \\
\text { NOx analyzer }\end{array}$ & $0-5000$ & $1 \mathrm{ppm}$ & $1 \mathrm{ppm}$ & $\pm 1 \mathrm{ppm}$ \\
\hline
\end{tabular}


Experimental Investigations on Injection Timing Variation at an Injector Opening Pressure of 190bar on Semi- Adiabatic Diesel Engine with Exhaust Gas Recirculation

\section{RESULTS AND DISCUSSION}

\subsection{Double Pipe Heat Exchanger}

Heat exchanger transfers the energy from a hot fluid to a cold fluid, with maximum rate and minimum investment and running costs. A concentric -pipe heat-transfer apparatus is employed. The principle of heat exchanger was employed that is heat lost by hot fluid (exhaust gas) is heat gained by cold fluid (ambient air). The length of the heat exchanger was calculated by knowing mass flow rate of fluid and temperatures of hot and cold fluid [Kern, 1963].The optimum EGR was found to be $10 \%$ of the total mass flow rate.

\subsection{Exhaust Emissions}

Fig. 4 shows the variation of particulate emissions with brake mean effective pressure (BMEP) with different versions of the engine with neat diesel, at various injection timings at an injector opening pressure of 190bar. A rich fuel-air mixture resulted in higher particulate emissions because of the availability of oxygen was less. The value of particulate emissions increased from no load to full load in both versions of the engine. During the first part, the particulate emissions were more or less constant, as there was always excess air present. However, in the higher load range there was an abrupt rise in particulate emissions due to less available oxygen, causing the decrease of oxygen-fuel ratio, leading to incomplete combustion, producing more soot density. The variation Up to $80 \%$ of full load, drastic reduction of particulate emissions was observed in the both versions of the engine. Increased oxidation rate of soot in relation to soot formation might have reduced particulate emissions. Higher surface temperatures of engine with LHR combustion chamber aided this process. Beyond $80 \%$ of full load, marginal and slight increase of particulate emissions was observed in the LHR engine, when compared to CE. Fuel cracking at higher temperature might have increased. Higher temperature of engine with LHR combustion chamber produced increased rates of both soot formation and burn up. The reduction in volumetric efficiency and oxygenfuel ratio were responsible factors for increasing particulate emissions in the LHR engine near the full load operation of the engine. As expected, particulate emissions increased in the LHR engine because of higher temperatures and improper utilization of the fuel consequent upon predominant diffusion combustion. Particulate emissions were observed to be less at all loads in both versions of the engine, with advanced injection timings. Increase of oxygen-fuel fuel ratios and atomization of fuel might have caused effective combustion in both versions of the engine at their respective optimum injection timings.

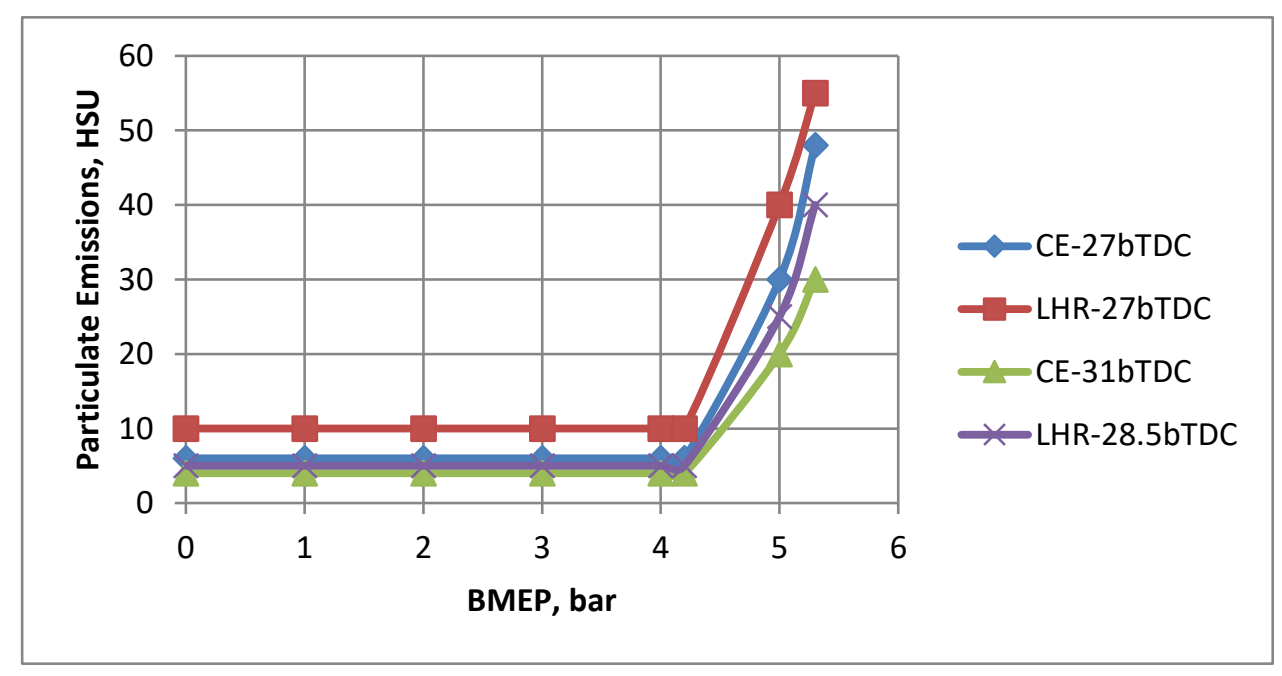

Figure 4 Variation of particulate emissions with brake mean effective pressure (BMEP) of the engine with different injection timing for CE and LHR engine 
Fig. 5 presents bar charts showing the variation of particulate emissions with provision of EGR and without EGR for both versions of the engine at different injection timings with neat diesel operation.

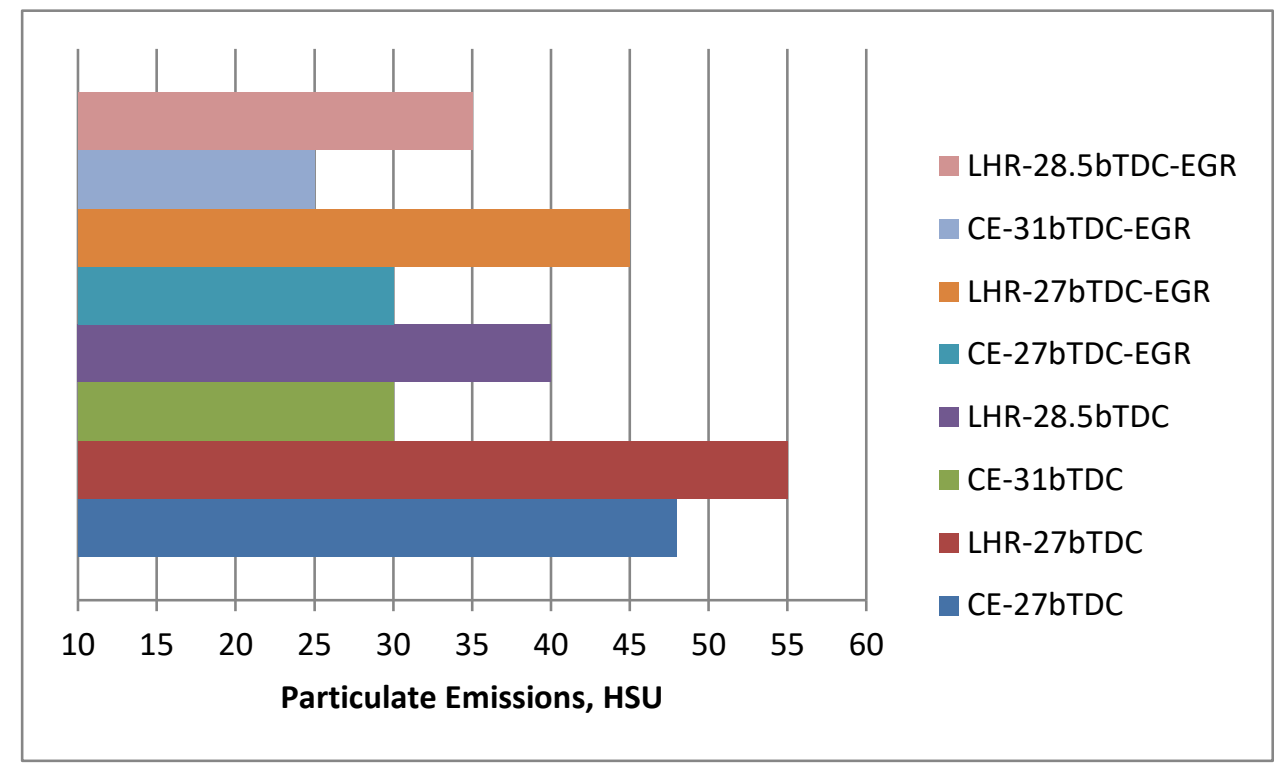

Figure 5 Bar charts showing the variation of injection pressure and particulate emissions with provision of EGR

Particulate emissions decreased with the provision of EGR. Combustion improved with increase of mass flow rate of EGR up to $10 \%$ leading to reduce particulate emissions with both versions of the engine at different injection timings. CE at its advanced injection timing with EGR reduced particulate emissions considerably in comparison with LHR engine. Increase of fuel cracking increased particulate emissions with LHR engine.

Fig. 6 shows the variation of nitrogen oxide levels $\left(\mathrm{NO}_{\mathrm{X}}\right)$ with brake power with different versions of the engine with neat diesel, at various injection timings at an injector opening pressure of 190 bar.The temperature and availability of oxygen are the reasons for the formation of $\mathrm{NO}_{\mathrm{x}}$. For both versions of the engine, $\mathrm{NO}_{\mathrm{x}}$ concentrations raised steadily as the fuel/air ratio increased with increasing BP/BMEP, at constant injection timing. At part load, $\mathrm{NO}_{\mathrm{x}}$ concentrations were less in both versions of the engine. This was due to the availability of excess oxygen. At remaining loads, $\mathrm{NO}_{\mathrm{x}}$ concentrations steadily increased with the load in both versions of the engine. At peak load, with higher peak pressures, and hence temperatures, and larger regions of close-to-stoichiometric burned gas, $\mathrm{NO}$ x levels increased in both versions of the engine. Increasing the injection advance resulted in higher combustion temperatures and increase of resident time leading to produce more $\mathrm{NO}_{\mathrm{x}}$ concentration in the exhaust of $\mathrm{CE}$ at its optimum injection timing. At the optimum injection timing, the LHR engine produced lower $\mathrm{NO}_{\mathrm{x}}$ emissions, at all loads compared to the same version of the engine at the recommended injection timing. Decrease of combustion temperatures might have lowered $\mathrm{NO}_{\mathrm{x}}$ emissions with advanced injection timing with LHR engine. However, $\mathrm{NO}_{\mathrm{X}}$ emissions were marginally lower in the LHR engine when compared to the CE at their respective optimum injection timings, due to increase of residence time in the $\mathrm{CE}$. 
Experimental Investigations on Injection Timing Variation at an Injector Opening Pressure of 190bar on Semi- Adiabatic Diesel Engine with Exhaust Gas Recirculation

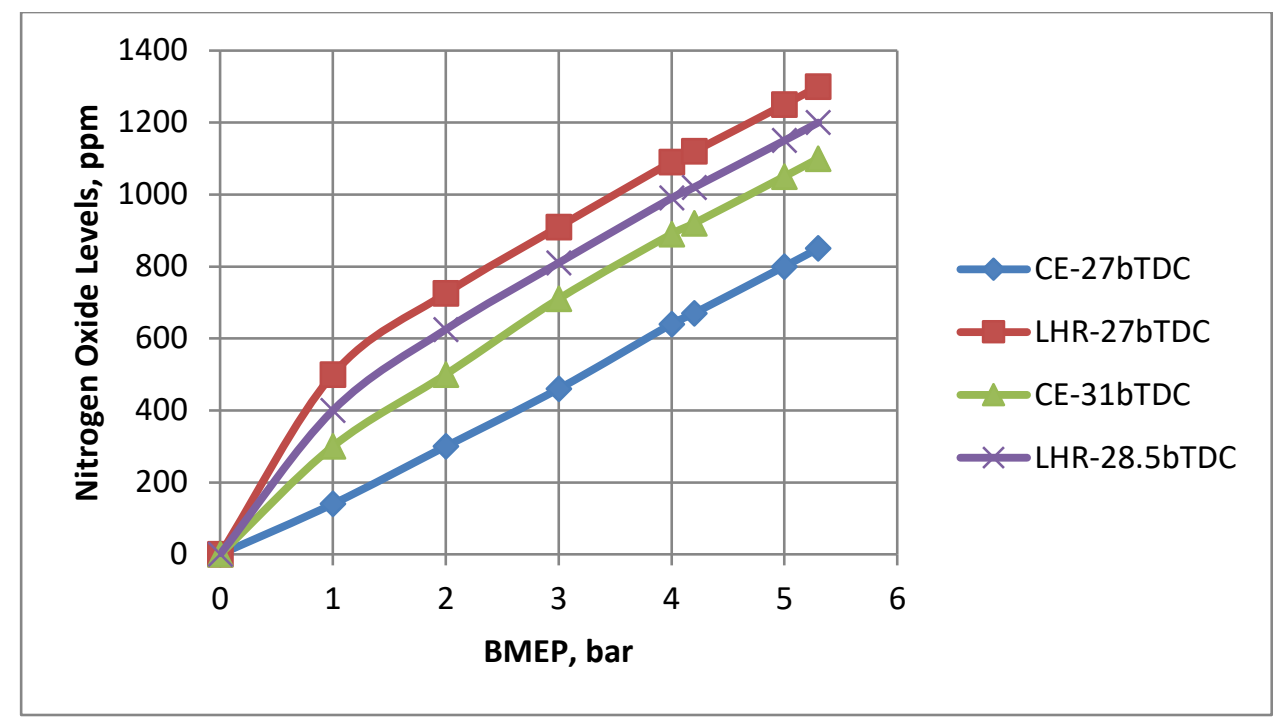

Figure 6 Variation of injection timing at an injector pressure of 190 bar, Variation of nitrogen oxide levels with brake mean effective pressure (BMEP) of the engine

Fig. 7 presents bar charts showing the variation of particulate emissions with provision of EGR and without EGR for both versions of the engine at different injection timings with neat diesel operation.

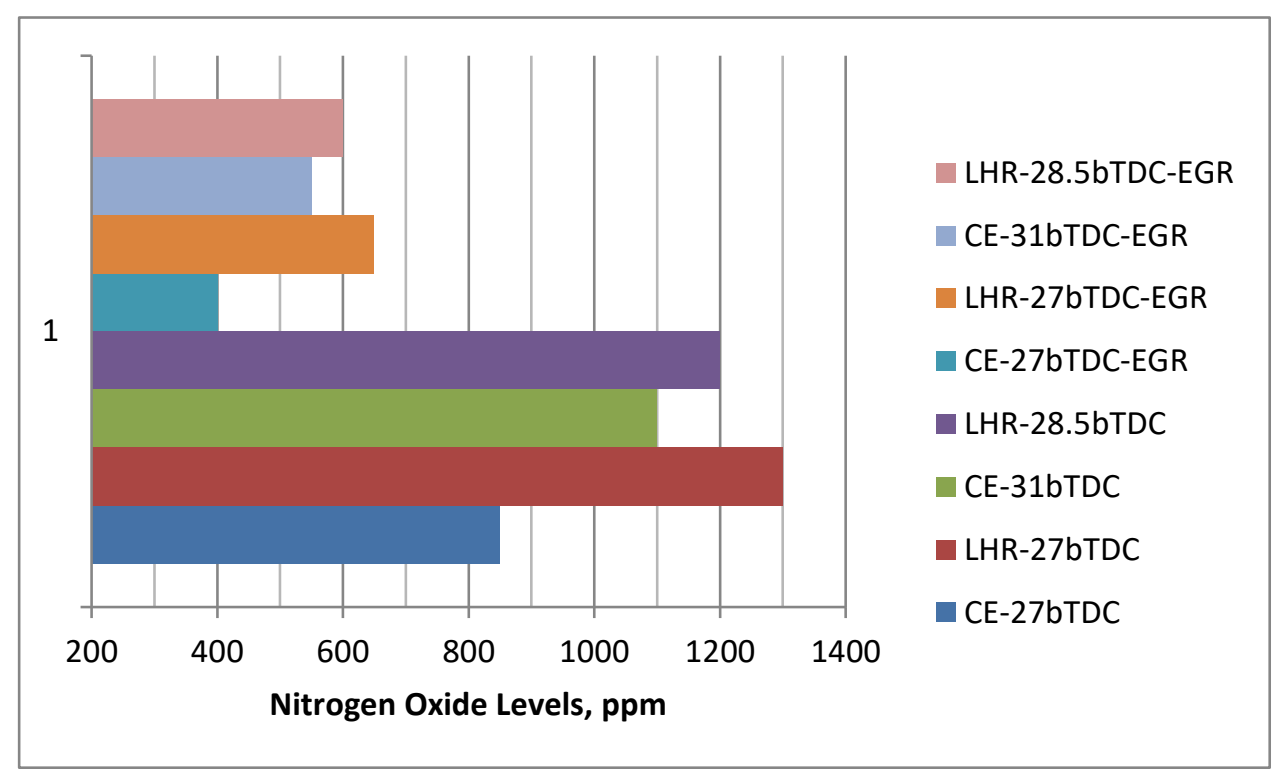

Figure 5. Bar charts showing the variation of injection timing with injector pressure of $190 \mathrm{bar}$.

Nitrogen oxide levels decreased with provision of EGR with both versions of the engine at different injection timings with neat diesel operation. Reduction of supply of oxygen might have reduced $\mathrm{NO}_{\mathrm{x}}$ emissions with EGR up to $10 \%$ mass flow rate.

\section{CONCLUSIONS}

On the basis of advanced injection timings

- At advanced injection timing, LHR engine reduced particulate emissions and nitrogen oxide levels

- At advanced injection timing, Conventional engine reduced particulate emissions and increased nitrogen levels 
On the basis of version of the engine:

- LHR engine marginally increased particulate emissions in comparison with conventional engine

- LHR engine drastically increased nitrogen oxide levels in comparison with conventional engine

On the basis of EGR

- With provision of EGR, thermal efficiency improved up $10 \%$ of mass flow rate, particulate emissions and nitrogen oxide levels considerably decreased

\section{ACKNOWLEDGEMENTS:}

Authors are thankful to the authorities of Chaitanya Bharathi Institute of Technology, Hyderabad for providing facilities for carrying out this research work.

\section{REFERENCES}

[1] Celikten C. 2003. An experimental investigation of the effect of the injection pressure on the engine performance and exhaust emission in indirect injection diesel engines. Applied Thermal Engineering 23:2051-2060.

[2] Cole R.M and Alkidas A.C. 1985. Evaluation of an air-gap-insulated piston in a dividedchamber diesel engine. SAE Paper No. 850359, 1985.

[3] Donald Kern. 1963. Process heat transfer, TMH, NewYork,

[4] Heywood J.B. 2013. Internal Combustion Engine Fundamentals, Tata McGraw Hills, New Delhi.

[5] Jabez Dhinagar. S.,Nagalingam .B. and Gopal Krishnan. K.V., 1993. A comparative study of the performance of a low heat rejection engine with four different levels of insulation, Proceedings of IV International National Conference on Small Engines and Fuels,121-126, Chang Mai, Thailand.

[6] Janardhan N., Usha Sri.P.,Murali Krishna M.V.S.,and Murthy P.V.K . 2012.Performance of biodiesel in low heat rejection diesel engine with catalytic converter., International Journal of Engineering and Advanced Technology 2(2):97-109.

[7] Li.G., Eisele. M., Lee.H, Hwang. Y. and Radermacher.Y 2014. Experimental investigation of energy and on Combustion and Energy Utilization, exergy performance of secondary loop automotive air- conditioning systems using low-GWP (global warming potential) refrigerants. Energy 68:819-31.

[8] Murali Krishna M.V.S., Seshagiri Rao. V.V.R., Kishan Kumar Reddy.T. and Murthy.P.V.K. 2014 Performance evaluation of high grade low heat rejection diesel engine with carbureted alcohol and crude jatropha oil, Renewable and Sustainable Energy Reviews 36:1-19.

[9] Murali Krishna M.V.S., Ohm Prakash.T., Usha Sri.P., and Krishna Murthy.P.V. 2015. Experimental Investigations on direct injection diesel engine with ceramic coated combustion chamber with carbureted alcohols and crude jatropha oil, Renewable and Sustainable Energy Reviews 2015; 53:606-628.

[10] Murali Krishna M.V.S, Seshagiri Rao.V.V.R.,Kishan Kumar Reddy.T and Murthy. P.V.K. 2014. Performance evaluation of medium grade low heat rejection diesel engine with carbureted methanol and crude Jatropha oil, Renew Sustain Energy Rev 34: 122-135.

[11] Vamshi Krishna K., Ravi Kiran Sastry.G., Murali Krishna.M.V.S. 2018. Performance and emission characteristics of EGR coupled with semi adiabatic diesel engine fuelled by DEE blended rubber seed biodiesel, International Journal of Engineering Science \& Technology 21:122-129. 